Where did we come from? The Emergence and Early Development of Voluntary Sector Studies in the UK

A paper submitted to Voluntary Sector Review, August 2015.

Revised January 2016 following editor's and reviewers' comments Final Version submitted at 26 January 2016

Key words: voluntary sector studies; academic field; field history; non-profit studies

Author contact:

Margaret Harris. Ph.D.

Emeritus Professor, Aston University, Birmingham, England and Visiting Professor Birkbeck, University of London

m.e.harris@aston.ac.uk

Tel. 07860907779 


\title{
Where did we come from? The Emergence and Early Development of Voluntary Sector Studies in the UK
}

\author{
Abstract \\ This paper considers how the field of voluntary sector studies (VSS) in the UK emerged. Drawing on \\ published and unpublished documents as well as on semi-structured interviews with people involved \\ in the early development of VSS, a time-line is suggested of key events. The analysis reveals both \\ social and cognitive elements in the field's development and considers the broader policy and \\ institutional context within which key events of the VSS field occurred.
}




\section{Introduction}

In 1995 a group of UK researchers, mostly academics, made a decision to form the 'Voluntary Sector Studies Network' (VSSN) (Halfpenny et al, 2005). Since then, VSSN has run bi-annual, well-attended day-long seminars as well as an annual conference (in partnership with NCVO, the National Council for Voluntary Organisations and IVR, the Institute for Volunteering Research). In 2010 VSSN supported the start of Voluntary Sector Review (VSR), this UK-based academic journal. The publication of VSR and the formation of VSSN (1) reflected a wish amongst researchers in the broad area of 'voluntary sector studies' (VSS) to support each other's scholarly endeavours. Although definitional debates continue, research and teaching on the voluntary ('third', 'NGO', 'nonprofit' or 'civil society') sector have become part of the UK academic landscape. Education institutions have appointed staff to specialise in the area and courses and research centres have been established.

These developments reflect recent patterns in other countries: the study of non-governmental, nonprofit-seeking organisations has expanded worldwide in the last 20 years, at least as measured by membership of scholarly associations and publication of peer-reviewed academic journals (D.H. Smith, 2013; Mendel, 2013). The developments also reflect literature about academic 'fields' which can be broadly defined as areas of special interest that develop within an established academic discipline (such as history or theology) or that cut across, or draw from, several disciplines (Becher and Trowler, 2001; Crane, 1972; Lewis, 2015; Mullins, 1973; Shapin, 1995). That literature sees collegiate social interaction around a common intellectual interest as a key signifier of field emergence.

Although 'voluntary sector studies' (VSS) can now be said to be established in the UK, it is also the case that, as in the US, the field appears to date only from the 1970s (later in other countries). Writing in 1990, Anheier and Seibel (p1) suggested that "The systematic investigation of the nonprofit sector in the United States began less than two decades ago, although of course traditional studies of charity, social welfare and cognate subjects had long existed ...". This statement could be applied equally to the UK; that is, a long tradition of studies of charities and voluntary action but, until the 1970s, no sense of a group of specialist scholars with a common focus and interest constituting a 'field'. In 2001, Harris and colleagues (Harris et al, 2001) were able to summarise the substantial body of "voluntary sector research" conducted in the UK between 1978 and 1998 under five headings: how do voluntary organisations differ from other organisations?; what organisations comprise the sector?; how is the sector resourced?; why do voluntary organisations exist?; and what is the voluntary sector's relationship with other sectors? 
The purpose of this paper then, is to record the early development of VSS in the UK. Where did we, as a collective of voluntary sector scholars, come from? What factors drove the field's emergence? In exploring these questions this paper aims to make a contribution to the history of VSS in the UK.

\section{Earlier literature on VSS in the UK}

As in the US, individual scholars have long been interested in aspects of philanthropy, charitable activity and community action but, at least until the 1970s, this was from within established academic disciplines such as history, law and political science, with little sense of common cause between scholars pursuing cognate research topics in the same or different disciplines. Alongside this, and dating from at least the late 1960s and early 1970s, there were indications that practitioners and policy makers were frustrated by the lack of information available to them about volunteering and 'voluntary organisations' (non-governmental, non-business organisations including registered charities, self-help groups and membership associations) . In fact the Aves Committee (Aves, 1969), which was funded by charitable foundations to examine the role of volunteers in social services - at that time mostly provided by local government - had to commission its own research in order to understand even the basic parameters of voluntary work and voluntary organisations at the time (2). Its report said "We are under no illusion about the wealth of study yet to be undertaken, both on some of the subject matter central to this enquiry and on other matters highly germane to it" (paragraph 13). In line with their frustration about lack of data, one of their recommendations was for the establishment of a "resource centre" (later the 'volunteer Centre' discussed below) which could collect information and conduct or commission research (Aves, 1973).

All the same, little progress was made immediately: “... despite the growth in the importance of volunteers 'on the ground' and in public policy, the basic analysis of voluntarism has only begun [in the late 1970s] to gain the momentum which might have been expected. Research continues to lag well behind the upsurge in discussion" (Webb, 1979: 11). Later in the same article (p.13) Webb, at that time a senior social policy academic, commented positively on the role of a later committee, the Wolfenden Committee (1978) (3), in commissioning research: "The Committee's first and surely its enduring contribution was to initiate a substantial body of research [on voluntary organisations]". Since the publication of Webb's piece, there have in fact been occasional attempts to review accumulated research across the UK field (e.g. Halfpenny and Reid, 2002; Harris and Billis, 1985; Leat, 1977; Selwyn, 1981). And there have been occasional suggestions for a research agenda to fill gaps in knowledge (e.g. Davis Smith, 2007; Handy, 1981; Harris, 2001c). 
As the field developed, there were also occasional critics of VSS scholars. 6 and Leat (1997), commenting on the Wolfenden Committee (1978, op cit) as well as the later Deakin Committee (1996) (4), criticised "academics and other intellectuals" for taking an uncritical and partial approach to the reports of those Committees. They argued that academics had been co-opted into the worldviews of voluntary sector infrastructure bodies, charitable foundations and other powerful institutions. Indeed, they accused VSS scholars in Britain of conniving - as Hall (1992), argued happened in the US - in the "invention" of the "sector". Another, rather different kind of critical note about the UK VSS field, and a possible explanation for its apparently slow development, was published in the (US-based) journal Nonprofit Management and Leadership (Palmer and Bogdanova, 2008). Regretting the demise of specialist teaching and research at the London School of Economics after a period of growth from the late 1980s, the authors argued that the income-maximising drive which had recently been imposed on British universities was a major barrier to voluntary sector teaching and research endeavour. Academics were now obliged, they argued, to limit their interests to those most lucrative for their home institutions, thus putting voluntary sector academics at a comparative disadvantage, since they mostly could not attract large research grants or high-feepaying students (5).

In spite of these occasional cautionary voices from within the UK, references by international authors suggest that UK voluntary sector scholarship has for some time been seen from abroad as well established and a key part of a global network of field scholars (eg Gidron, 2002; D.H.Smith, 2013; S.R. Smith, 2013). The study reported in the remainder of this paper aims to expand on these varied and limited published analyses about the development of VSS research in the UK.

\section{Study Approach}

I have been actively involved in the development of the VSS field since 1981 when - following a spell as a practitioner in a voluntary organisation - I was employed as a Research Officer at Brunel University; collaborating with David Billis on the development of PORTVAC (Programme of Research and Training on Voluntary Action established in 1978) and on the UK's first specialist postgraduate degree for voluntary sector practitioners (Billis and Harris, 1996; Harris, 2001a). Thus I am myself part of the story of the emergence of VSS in the UK and my involvement in the early history of VSS reflects methodological debates about the 'role of the self' in voluntary sector research (Harris, 2001b). I hope that by fully declaring my own position, I will enable readers to appraise the analysis presented below with an appropriately critical eye. I hope also that the advantages of being an 'insider' (in terms of facilitating access to records and informants) have, in this case, balanced out the limitations presented by my insider status. 
Two main approaches to data collection were employed for this study. One was examination of documentary evidence relating to the voluntary sector studies field (as distinct from documents relating to voluntary organisations and volunteering). In addition to the customary search for published and unpublished relevant literature, I accessed the archives of relevant institutions and projects in so far as they were available and photographed relevant documents. Potentially useful archives were identified during the literature review and interviews. In several cases it seemed from catalogue searches and personal enquiries that documents which would have been germane to this study (that is, those relevant to the scholarly field's emergence and development rather than records relating to individual charities or voluntary organisations) had never been archived or that their location was unknown.

A second data source was twelve semi-structured interviews with people who were involved with the field's establishment and/or early development. The aim of the interviews was to fill gaps in the historical narrative provided by the documents search; to provide a cross-check between different sources of data on matters of fact; and to provide a range of perspectives on the emergence and early development of the field - perspectives additional to those provided in written sources.

This approach of collecting data through both documents and interviews was intended to provide information on matters of fact (eg the founding dates of relevant organisations) as well as perspectives from a range of sources on matters of recollection and personal experience. The two data collection procedures were conducted in parallel and informed one another. For example some interviewees suggested locations of possibly relevant archives and some interviewees were themselves approached because the literature and documentary searches suggested they might be appropriate key informants for the study.

At the start of this study I had short, exploratory conversations with three senior academics ('senior' in both senses of the term) to explain the aim of the study and to seek suggestions about people to be interviewed. Using these informal soundings, as well as a preliminary review of literature on academic fields (e.g. Becher and Trowler, 2001; Crane, 1972; Mullins, 1973; Shapin, 1995), a semistructured interview schedule was drawn up. Interviews were then conducted with three further academics, all now retired, who have published extensively on voluntary sector matters and whose work is widely cited by VSS scholars in the UK and internationally. These first three interviews provided the starting point for a snowball approach to identifying further interviewees; people who were thought by their peers to have played key roles in the emergence of VSS in the UK. As people were identified, they were traced and asked to agree to a face to face interview. The process was terminated after the twelfth such interview as no new names of potential key informants with 
potentially different perspectives were being identified. Given the topic being researched and the limited number of actors associated with the field in its earliest years, this number of interviewees seemed to be an acceptable response to the saturation sampling approach taken (Crouch and McKenzie, 2006).

Interviews took place between December 2013 and October 2014. All interviewees were promised anonymity so viewpoints are not attributed in this paper; but all interviewees also agreed to be listed and acknowledged by name in publications (see Appendix). Three interviewees were women and nine were men. Seven were first involved in voluntary sector research in the 1970s or before; the remainder in the 1980s. The interviewees included not only researchers based in universities and sector infrastructure bodies, but also people involved in supporting research on charities and voluntary organisations. Eight of the twelve had been involved in voluntary action, community activism and/or political advocacy prior to becoming involved in VSS.

Interviewees were asked to comment on: how they became involved with 'voluntary sector studies'; the idea of a voluntary sector studies 'field'; and their perceptions of key people, events and institutions in the early development of the field. Many interviewees suggested published and unpublished documents which they felt had contributed to, or recorded, field development. Some also provided their own written accounts of their career trajectories.

Draft notes were returned to interviewees for modification and additions. Publications suggested as being relevant by interviewees were sourced and then incorporated into the literature review (above) or into the historical timeline (below) as appropriate. Archived documents were traced and relevant material photographed. This material was used to develop the literature review and a timeline as well as to supplement interview data. Finally, individuals who were thought to have access to particular documents of relevance or who might provide details of particular events were contacted.

\section{Study Findings}

\section{A Tentative Timeline}

Using the results of the document search as well as information offered by interviewees and other contacts (Appendix), a timeline of key points in the emergence of the VSS field in the UK (up to the early 1990s) was constructed (Figure, left hand column). Most interviewees saw key developments as having been closely tied to contemporary institutional and policy events (Figure, right hand column). Thus the Figure presents (on the left) points arising from the document review or interviews as being key milestones in the early development of the field (roughly up to the time of 
the establishment of VSSN in the 1990s). The right hand column refers to other events or trends which were roughly contemporaneous and possibly linked in some way to events listed in the left hand column. Where interviewees or documents specifically linked VSS events with other contextual events, the two are shown in the same horizontal plane (without judgement about whether they were causally linked).

Neither column is necessarily comprehensive and the Figure should be seen as a first attempt to build a historic record of the emergence and early development of VSS in the UK. Yet it is a record which moves beyond listing key events and acknowledges the ways in which those events were likely driven by, and in turn drove, other factors in their policy and institutional environment (di Maggio and Powell, 1983) (6).

[Insert Figure about here]

Interviewees not only provided information about dates and events in the early development of VSS in the UK, they also added texture to bare facts through their perceptions of both cognitive and social elements (Becher and Trowler, 2001) in the early development of the field. These interview data are presented in the next subsections with brief illustrative quotes shown in italics.

\section{Cognitive and Social Constituents of VSS in the UK}

All interviewees recognised not only the general concept of an 'academic field' or a 'field of studies', but also the idea of 'voluntary sector studies' (or something with a similar name):

"The idea of a voluntary sector studies field resonates with me. There is a specialist field of study" and "I had a sense of colleagues who were interested in the same broad research area as me."

Interviewees thought that participation in voluntary sector-themed seminars and conferences ("an iterative process of meeting each other") was the most important indicator of field 'membership' . Participating in specific historical events was often crucial for a sense of belonging. Three such events were mentioned by several interviewees.

1. The formation of ARVAC (Association for Research in the Voluntary and Community Sector) in 1976 (7). This was thought to have "started the feeling of community between researchers".

2. The 1990 Conference of the US-based association AVAS (Association of Voluntary Action Scholars, later ARNOVA, (Association for Research on Nonprofit Organizations and Voluntary Action) , hosted by the Centre for Voluntary Organisation at the London School of Economics 
This was said to have been "important in bringing together UK researchers" and in "opening up a new dialogue".

3. The meetings held 1993-5 at the London School of Economics of a seminar series "Challenges for Voluntary Agencies in a Changing Social Policy Environment" funded by the ESRC (Economic and Social Research Council). These were said to have been important “... in giving an opportunity to follow through particular themes systematically" They culminated in a group decision to form the Voluntary Sector Studies Network .

Interviewees differed in their perceptions of how long they themselves had been part of the field. Some thought of themselves and others as having devoted most of their careers to research and teaching around the voluntary sector; while some were active in the field for relatively short periods, e.g. "I moved in and I moved away from looking at the sector as my primary focus ...". Such 'visitors' entered the field from (and later returned to) a 'home' discipline (e.g. economics, sociology, history or law) or an adjacent academic field (e.g. social policy or public administration). The visitor point also applied to employees of voluntary sector infrastructure organisations whose involvement in the field was bounded by their time in relevant posts.

There were also thought to be some scholars whose work was respected by voluntary sector scholars but who did not apparently see themselves as part of the field. This was often thought to reflect disciplinary rivalries; for example: "Politics academics ... tend to think that civil society is a topic and theoretical domain which belongs exclusively to their discipline- though they have produced interesting and relevant [to the voluntary sector field] studies." In short a picture emerged of the VSS field as one whose existence was widely recognised but one that was understood to have "grown from different directions."

Several interviewees thought that the most committed participants in the VSS field were those who had empathy with the voluntary sector and volunteering, not simply as a topic of study but because they had had relevant personal experience - of being a recipient of sector services, as an active member of a voluntary organisation, or as a long-term volunteer or sector employee. Such experiences piqued their curiosity about the role and function of volunteering and voluntary organisations and made them "gravitate to people who have done it and understand it".

For some, participation in the field was seen as serving a social function beyond collegiate networking - keeping up the morale of those engaged in a minority area of study. This collegiality was especially valued as the field initially emerged. In the post-World War II period, until at least the late 1970s, academics concerned with provision of public services largely ignored services provided 
by non-governmental agencies; an approach dubbed "etatist" by one interviewee and "the pure theory of the welfare state" by another. The outcome for early voluntary sector scholars was that they could feel marginalised within academia more broadly. Having a few close colleagues with similar interests was a form of psychological mutual aid.

In addition to these perceptions, which largely refer to 'social elements' of the field, there was a variety of understandings about its 'cognitive elements' (Becher and Trowler, 2001). Some interviewees felt that VSS should focus on the collection and updating of descriptive quantitative data: "I felt research was important because there were no facts." Others felt the field should be about critical evaluation. Still others were most interested in explaining organisational manifestations of the voluntary sector or analysing public policy about the sector.

Interviewees wrestled with the question of which areas of knowledge were, or could be, included within the VSS field. Amongst the areas of study mentioned as central were volunteering, community work and financial management. Some other topics were mentioned in a negative context; they were thought to be outside the field or on its boundary. These included philanthropy; charity law; social movements; management; and civil society. One interviewee, while approving of the study of voluntary organisations and voluntary action, thought that it was inappropriate to study them in isolation from public policy and practice issues: "you cannot get very far by looking at it on its own". In short, there was little consensus about which areas of study are, or should be, encompassed by VSS, although there was a consensus that such a field is recognisable.

Few saw the field as comprising only academics employed in higher education institutions. It was thought that governmental departments, charitable foundations and voluntary sector infrastructure bodies - as well as 'think tanks' in the 1970s and 1980s - had played a key role in the early development of the field, not only in commissioning and employing researchers and publishing their findings, but also by giving financial and other support to seminars and conferences which brought together those doing specialist research (see, for example, Lee,1989).

Some interviewees perceived a link between the development of the academic field and trends in public policy; although there was variation in the extent to which this was seen as a causal or symbiotic link. One interviewee was clear that: "The content of the [voluntary sector] research agenda has been shaped by government". Others thought that the academic field of voluntary sector studies emerged and was sustained by other factors, including the needs of the sector itself for information and credibility: "[For the sector] it's functional to have a field and somebody to clarify ideas and critique them." Another factor was thought to be the growing awareness by statutory 
sector social workers during the 1970 s of the contribution to social welfare provision of volunteers, voluntary organizations and informal care. Once it emerged, the field was seen to have been sustained by factors including voluntary agencies' own "sense of commonality" and the cohorts of students taught by academics engaged in specialist research: "Where you have students who are learning , you get regeneration of knowledge."

\section{The Emergence of the Field}

Most interviewees thought that the intellectual roots of the VSS field were planted during the 1970s, a viewpoint which reflects the literature. Many noted that although there had been UK studies (often historical) before that decade and mostly focused on philanthropy, charity law and individual charities, it was only during the 1970s that a feeling of common purpose developed amongst researchers, alongside the first systematic gathering together of disparate earlier findings relating to voluntary organisations and voluntary action (Gerard, 1983; Leat, 1977; Selwyn, 1981). Several factors were suggested as having contributed to, and reinforced, this sense of commonality. One was the growing awareness amongst academics and policy makers about the contribution being made by volunteers and charities to the provision of social care: "My interest in volunteers and voluntary organisations was from the perspective of my interest in social services."

In the post- World War II Welfare State era, academic attention had largely focused on care by statutory sector social workers, and few had paid attention to the complementary and supplementary services provided by charities; to the contributions of volunteers; or to new self-help and citizens' organisations. This started to change in the late 1960s with the publication of the Seebohm Report on the future of personal social services (Home Office, 1968) and the Aves Report (Aves, 1969). The Aves Committee not only gathered together a number of research studies on "voluntary workers" carried out during the 1960s, it also commissioned some research of its own into the nature of volunteering (Aves Committee Minutes, 1966-69) .

One of the Aves Report recommendations led in 1973 to the establishment of what became the Volunteer Centre. This new, independent, organisation not only had a brief to bring together resources relating to volunteering, it also brought together physically a number of senior figures in charitable foundations and social services provision to serve on its governing board and committees, including Lord Seebohm and (later Dame) Geraldine Aves. The establishment of an institutional hub and the association with it of senior figures of the social care world, not only served to raise the profile of volunteering but also apparently encouraged some young researchers to see 
the role of volunteers as an interesting topic for research (Hadley, Webb and Farrell, 1975; Leat, 1977).

The embryonic specialist research community was expanded and given further support towards the end of the decade as the researchers for the Wolfenden Committee (1978) started producing data and policy recommendations about what they termed 'voluntary organisations' and 'the voluntary sector'. The Committee's Senior Researcher, Stephen Hatch, received additional funding from the Joseph Rowntree Memorial Trust to continue research on the voluntary sector after the Wolfenden Committee had reported. Based at the Policy Studies Institute, Hatch and others (including lan Mocroft and Diana Leat) constituted a small hub of specialist researchers in the early 1980s. Between them they had a variety of professional links to others researching volunteering and voluntary action at that time, including former colleagues at the Volunteer Centre, NISW (National Institute for Social Work) and the LSE Department of Social Policy and Administration(8).

Also towards the end of the 1970s, a conference sponsored by the Volunteer Centre on voluntary action and community involvement found sufficient common cause amongst attendees to encourage the setting up of ARVAC (7) as the UK's first association of researchers with an interest in the voluntary and community action. Once established, ARVAC further consolidated the specialist research community through organising meetings, publishing working papers and facilitating knowledge-sharing: "It ran workshops and created a community sense ... after we came together as researchers we found common interests in the voluntary sector." ARVAC attracted academic researchers as well as community-based researchers and policy analysts.

The research conducted for the Wolfenden Committee had a clear influence on public policy in that it spotlighted 'welfare pluralism'; the idea that welfare services could be provided by non-state agencies alongside state agencies and that funding and provision of services did not necessarily have to be done by the same agency or within the same sector. This idea, which challenged earlier consensus about the Welfare State, was initially grounded in assumptions about the complementary, empowering and participative nature of non-state agencies; it gained traction in policy discourse well before the Conservative Government of Margaret Thatcher turned its attention to the voluntary sector as a way of implementing neo-liberal policy objectives of reducing state provision (Hadley and Hatch, 1981; Hall et al, 1975; Hatch, 1980; Johnson, 1987; Webb, 1985). As it gained ground, the concept of welfare pluralism gave a further fillip to researchers of welfare services who were beginning to recognise the actual and potential welfare role of the voluntary sector - as well as, or instead of, the governmental sector. 
This early development of VSS was supported and encouraged by funding from both central government and charitable foundations. Both the Volunteer Centre and ARVAC received modest support in their early stages from the Home Office, the government department which acquired specific responsibility for voluntary sector matters in the 1970 s as governmental interest in nonstate service delivery increased. The Aves and Wolfenden Committees were funded by large charitable foundations with a social welfare focus and a consequent interest in the actual and potential role of voluntary organisations and volunteering in welfare policy and provision. Similarly, PORTVAC at Brunel University (Programme of Research and Training on Voluntary Action, later CVO or Centre for Voluntary Organisation at the LSE) was initially funded by grants from charitable foundations interested in promoting the systematic study of voluntary organisations as potential alternatives to Welfare State provision.

\section{The Early Development of the Nascent Field}

Stages in the growth of VSS can be traced on the left of the Figure, reflecting how researchers from various disciplines and fields involved themselves for varying periods of time. Articles about aspects of the sector were published in national and international academic peer reviewed journals -often ones focusing on public administration or social policy, there being no enduring specialist UK academic journal until 2010 (9). Participants in the VSS field started to find the published research of academics working in areas with which they had been unfamiliar, such as self-help and mutual aid; social movements; co-operatives; neighbouring; charity law, and the 'third' or 'non-profit' sector outside of the UK. Academics who had thought they were ploughing a narrow furrow without empathetic colleagues started to make links with others with broad interests in the voluntary sector and volunteering; initially through ARVAC and later through participation in conferences in the UK and abroad (mostly in North America and Western Europe). Thus the field grew from a number of different cognitive directions and researchers learned to talk across international and disciplinary boundaries about their common topic focus.

From the mid-1980s, UK universities started to offer taught courses (many grounded in research findings of the teachers) relating to voluntary organisations, volunteering and community involvement (Billis and Harris, 1996; Cornforth et al, 1998). As students graduated from these courses there was a multiplier effect on the public and academic perception of the voluntary sector and the VSS field. Opportunities for doctoral level study were opened up in the university departments where teaching and research was already based. 
Often UK researchers found each other through conferences and seminars in other countries: "[An ARNOVA Conference in the US] ... was the first time l encountered lots of people with the same broad interest ... at that time I had no sense of an academic field in the UK". Visits to the UK by David Horton Smith in the 1970s and Ralph Kramer in the 1980s (the former primarily to the Volunteer Centre and the latter primarily to the Centre for Voluntary Organisation at the LSE), both prominent US researchers and writers on non-profits and voluntary action, helped to make links across disciplines and to provide ideas about theories applicable to voluntary sector organisations. "Ralph Kramer was important in creating a sense of a field" and "Ralph Kramer's [1981] book was important for showing international aspects of voluntary sector research and international comparisons".

These visitors from abroad also alerted UK scholars to potential colleagues outside the UK. By the end of the 1980s, UK researchers were starting to attend 'nonprofit' conferences in the US and elsewhere. In the 1990s, there was heavy UK involvement (money and personnel) in the foundation of two new international academic journals for the field: Nonprofit Management and Leadership and Voluntas. The former was co-founded by David Billis of the LSE with Dennis Young, then of Case Western Reserve University in the USA. Voluntas was originally owned by the London-based Charities Aid Foundation directed by Michael Brophy (10). As part of its mission to promote information and research about the charity sector, CAF underwrote the initial investment and a large part of the operating costs for the first three years (Anheier, 2002). UK scholars participated in increasing numbers in US-based and international conferences from the early 1990s and were involved in the governing bodies of both ISTR (International Society for Third Sector Research ) and ARNOVA, the US-based Association for Research on Nonprofit Organizations and Voluntary Action (Gidron, 2002) and the international Johns Hopkins comparative project (Kendall and Knapp, 1996).

Interviewees had a variety of memories and perceptions of the early development of the field. As reflected in the Figure, many thought there was a link between the development of VSS and shifts in UK public policy; although there were wide variations in perceptions of what the nature of that link had actually been. Some thought that the field had grown in lock-step with national government interest in the role of the voluntary sector and volunteering from the late 1970s onwards; that researchers had been opportunistic and had pursued research on the sector when encouraged by political interest in nongovernmental provision of services. Others pointed out that there had been only minimal governmental research funding (through the ESRC or through projects commissioned by central government departments) until the late 1990s and that this had inhibited the development of the field. 
Some interviewees thought that there had been such close interaction between the development of the field and public policy trends that cause and effect were hard to distinguish; that voluntary sector research had indeed been driven by public policy interests but that public policy directions had themselves been impacted upon by emergent findings of VSS research. Few interviewees had much more than an intuition about this process but three examples were provided of assumed research impact on public policy. It was suggested that research by Hatch and Mocroft (1977a and 1977b) and by Knapp and his colleagues (eg Knapp and Missiakoulis, 1982; Knapp, 1990) had helped to counter the assumptions of politicians in the 1980s and 1990s that the voluntary sector could provide similar services to those provided by governmental organisations - but more cheaply. More broadly, it was suggested that research-based work by Hadley and Hatch (1981) had helped to embed the idea of 'welfare pluralism' within public policy discourse during the 1980s. Another interviewee thought that research and intelligence-gathering conducted in the 1980s and published by the Charities Aid Foundation , particularly research on the financial resources of the sector, had helped to convince national government that the voluntary and charity sector was an important part of the British economy and that its infrastructure bodies should be consulted by policy makers.

Several interviewees explicitly addressed the question of the link between the perceived importance of the role of the voluntary sector and researcher interest in it. Some thought that the development of the field had been contingent on the arrival into it of particular academics who had already won their spurs in a mainstream discipline and were "academically pukka". Others felt that insofar as the field was respected by other academics or by policy makers, it was due to the activities of a few entrepreneurial and visionary individuals who were able to raise money for research they thought important. Against this, three interviewees thought that some academics had positively avoided studying voluntary sector topics because of their concern about threats to the future of the Welfare State; because they did not wish to endorse or encourage policy interest in alternatives to state provision of welfare.

\section{Reflections and Discussion}

The study presented here combined two research approaches - documentary analysis and interviews with participants in historical events. Key events and stages in the emergence of our field were identified not only through analysis of documentary evidence, but also through the recollections of those who lived through the period examined. Interview data helped to nuance descriptive material from documents and also provided policy and institutional context. Conversely, documentary evidence mitigated some of the known disadvantages of relying on individuals' 
memory about historical events and enabled the researcher to check dates and events recalled by interviewees.

In this way, this paper has been able to explore factors in the emergence and early development of VSS in the UK. For example, it notes that a strong motivator for those involved in VSS in the 1970s and 1980s was a 'gap in knowledge'; a traditional driver of academic endeavour. The gap in in this case was identified initially by practitioners who felt that their own work was hampered by knowledge deficits. Thus academics and research entrepreneurs were initially reactive and early work was mostly descriptive and involved drawing together and analysing existing quantitative data and other research findings.

A further factor in the emergence of the VSS field was the sense of mutual support and collegiality between voluntary sector researchers which existed from at least the late 1970s. Yet the intellectual roots of those researchers' interests were varied. Some were well established in a particular academic discipline (such as economics, law or political science) and some in other academic fields (such as social policy or public administration). They were keen to remain identified primarily with those intellectual bases and their interest in volunteering or voluntary organisations was part of a broader intellectual quest. Such people were seen as specialist voluntary sector researchers for relatively short periods of time. Others, by contrast, seem to have identified more closely with VSS as an emergent field in its own right; one which could provide a focus for their research careers. These latter often had personal experience of volunteering or voluntary organisations and consequently were interested in studying concepts which they had encountered in practice such as citizen participation, voluntary association, management and civil society.

Although the backgrounds of early VSS researchers were varied, it seems that many of those who drove the earliest development of the field had links as staff or students with the LSE's Department of Social Policy and Administration. Their interest in researching volunteering and voluntary organisations developed alongside growing public policy interest in the delivery of welfare services by non-statutory agencies. In the minds of interviewees, these two developments were linked and yet interviewees varied as to the extent to which they thought they were causally linked.

The research reported here may be seen as a case study of the emergence of an academic field. In that context, the question arises from this case account of why it took more than two decades for an overtly scholarly association (VSSN) to be formed and even longer for a sustainable specialist academic journal (VSR) to be published. Perhaps the early formation of ARVAC as a communityfocused research association partially fulfilled the mutual support needs of early specialist 
researchers and discouraged academic separatism in the early years. Similarly, perhaps the willingness of established UK journals - such as Community Development, Social Policy and Policy and Politics - to consider submissions focused on voluntary sector matters provided sufficient fora for a while. Later, as specialist international journals beyond JVAR (Journal of Voluntary Action Research, later NVSQ or Nonprofit and Voluntary Sector Quarterly ) emerged (for example, Voluntas, Nonprofit Management and Leadership and Third Sector Review) they provided further possible destinations for UK based research papers, and perhaps crowded out demand for a UK-based specialist peer-reviewed journal.

These and other questions would lend themselves to discussion in a symposium attended by researchers who participated in the early development of VSS and who could contribute personal recollections and perspectives to enlarge on those recorded here; or perhaps a debate within the pages of an academic journal. The generic literature on the emergence of academic fields suggests that the infrastructural institutions of fields tend to emerge organically in response to felt need and critical mass of participants in a field. From this perspective, it is perhaps not surprising that the launch of a scholarly association and scholarly journal did not occur until there was clear evidence of sufficient interest to sustain them.

The examination of VSS could now be taken in at least two further directions. One direction would compare the emergence and early development of our field with the emergence and early development of other academic fields in the UK and internationally. The period from the emergence of our field to the establishment of a specialist scholarly association and journal covers a period of more than 25 years. To what extent does the pattern of VSS emergence and development mirror that of other fields? Is this a usual pattern for nascent academic fields or were there some special features in the UK which slowed down the early development? Do comparisons with other fields and countries yield any lessons for the future of VSS in the UK?

A second research direction would continue the narrative which this paper has started, by exploring and recording the development of VSS beyond the initial stages and beyond the birth of VSSN. Such a study could include a detailed examination of the extent and nature of the links between the development of VSS and concurrent trends in public policy, higher education, the role of the voluntary sector and the availability of external funding for specialist research. Is there a discernible flow of causality between the field and the contextual factors identified? Is there simply an inchoate flow of ideas and people across the two domains as suggested by one anonymous reviewer of this manuscript? Has the VSS field largely been marching to the beat of contextual drums? Or has the 
field emerged and developed as a reflection of researchers' ambitions to produce work which is policy- and practice-relevant?

The history of the emergence of our voluntary sector field deserves to be recorded while the founding parents are able to contribute recollections and tell us about the location and content of archives additional to those analysed for this paper.

\section{Endnotes}

(1) In 2014 VSSN had 162 members. The more specialist VAHS (Voluntary Action History Society) had 52. .

(2) Finnegan and Brewis $(2012$, p3) explain in their preamble to the Aves Committee archive that this was "an independent commission on the place of and scope for volunteers in the social services in England and Wales and was set up by the National Council of Social Services (afterwards the National Council of Voluntary Organisations, NCVO) and the National Institute of Social Work Training, NISW. Since 1919 the National Council of Social Service provided support and advice to voluntary workers and the organisations that involved them ... by the late $1960 \mathrm{~s}$ demand was growing for a specialist national centre to promote and support the concept of volunteering as well as for the creation of organisations to help recruit and place volunteers at local level."

(3) The Wolfenden Committee's report 'The Future of Voluntary Organisations' provided the first overview of non-governmental provision of social welfare services since the post-World War II establishment of the welfare state and was funded by the Rowntree and Carnegie foundations. It commissioned research projects on volunteering and voluntary organisations and its report is thought to have been the first to refer to a 'voluntary sector'. Some of those who worked on the Wolfenden Committee research, including Stephen Hatch and lan Mocroft, went on to do further pioneering research on the voluntary sector in the 1980s (eg Hatch and Mocroft, 1977a and 1977b).

(4) The Commission on the Future of the Voluntary sector ('The Deakin Commission') was set up in 1995 'to provide a clear vision for the role of the voluntary sector in England over the next decade" (Deakin, 1996, inside front cover). Support was provided by two charitable foundations and the National Council for Voluntary Organisations, NCVO. Chaired and steered by a senior social policy academic it drew on existing voluntary sector research and commissioned some new research (Deakin, 1996). 
(5) Other academics, writing in more general terms about the impact of pressures since the 1990s on UK higher education, have pointed out how the Research Assessment Exercise and the Research Excellence Framework have impacted on academics' choice of research and teaching topics; discouraging them from taking risks and encouraging them to identify with established academic disciplines rather than new or marginal fields (eg Scott, 2013; Back, 2015).

(6) I am grateful to one of the anonymous reviewers of this manuscript who suggested that one might think of the Figure's two columns as listing two "domains" between which ideas, publications and people can be seen to "ebb and flow ...encouraging or restraining the development of the field at different times".

(7) ARVAC was established "to promote, disseminate and discuss research on voluntary organisations, volunteer involvement, community action, self-help and informal caring" and aimed to "link together researchers and provide a forum for them and others interested in the field" (Goldberg, 1984, cover page). ARVAC is now a totally volunteer-run association with free membership. It reported a membership of 600 in October 2014. Interviewees differed as to their recall of who drove the establishment of ARVAC. Some thought the idea was driven by lan Bruce while Director of the Volunteer Centre, while others thought that David Horton Smith, while on a visit to the Volunteer Centre from Boston College in the US, had proposed the setting up of a membership association similar to the US-based AVAS (Association of Voluntary Action Scholars) of which he was a founder.

(8) Many of the pioneers of the field in the 1970s and early 1980s, including David Billis, Roger Hadley, Stephen Hatch (widely credited with the invention of the 'voluntary sector' term), lan Mocroft and Adrian Webb were, or had been, students or staff members in the LSE's Department of Social Policy and Administration (later Department of Social Policy). The voluntary sector had come to their attention as part of their interest in the delivery of welfare services and the development of public policy. Later, in 1987, the Department became home to the Centre for Voluntary Organisation (CVO) and then, in 1999, the Centre for Civil Society. By the late 1980s several English universities including Kent, Manchester and the Open University also had small clusters of scholars interested in charities and voluntary organisations.

(9) This journal, Voluntary Sector Review, which began publishing in 2010, is the first UK-based voluntary sector peer-reviewed journal which has endured beyond its initial issues. 'Voluntas' which was initially established in the UK in 1990 as an international journal and supported by the Charities Aid Foundation, moved after its initial years to a US-based publisher and became the journal of ISTR (The International Society for Third Sector 
Research founded in 1992 ). The journal Nonprofit Studies was published in two issues only in 1997 and the Journal of Voluntary Sector Research appeared only once in 2008. The Institute for Volunteering Research published a journal called Voluntary Action between 1998 and 2006 but it was focused on volunteering rather than the voluntary sector more broadly.

(10) According to The Civil Society Directory

(http://www.civilsociety.co.uk/directory/company/283/charities_aid_foundation ) Charities Aid Foundation (CAF) is " a registered charity which aims to improve the way donations are made and how charities handle their finance." Michael Brophy CBE was Chief Executive of CAF for two decades from 1982. During his tenure he pro-actively encouraged research and intelligence gathering on the funding and finances of charities and other voluntary organisations and ensured that findings were published and widely disseminated - in annual publications such as 'Charity Statistics' (later, 'Dimensions of the Voluntary Sector'), in a monthly magazine called 'Charity' and in individual research reports. Some such work was conducted in-house by CAF staff and some commissioned from academic and other researchers. He was a driver behind the initial funding of Voluntas by CAF.

\section{Bibliography}

Anheier, H. (2002) Voluntas: The Early Years in ISTR: The First Ten Years in Celebrating ISTR's Tenth Anniversary Baltimore, MD: ISTR 25-34

Anheier, H. and Seibel, W. (eds) (1990) The Third Sector: Comparative Studies of Nonprofit Organizations NYC: de Gruyter

Aves, G. (1969) The Volunteer Worker in the Social Services ('The Aves Committee Report') London: George Allen and Unwin

Aves, G. (1973) Helping to Help New Society 4 January 15-16

Aves Committee Minutes 1966-69 included in The Volunteering England Archive Deposited in the Library of the London School of Economics

Back, Les (2015) Scholarly Life and the University in Ruins Keynote Address to the British Sociological Association Postgraduate Forum, November https://bsapgforum.wordpress.com/2015/11/29/lesback-scholarly-life-and-the-university-in-ruins/ [accessed 22 January 2016]

Barclay P. (1982) Social Workers: their role and tasks ('The Barclay Report') London: Bedford Square Press

Becher, T. and Trowler, P. (2001) Academic Tribes and Territories: Intellectual Enquiry and the Culture of Disciplines Buckingham: SRHE and Open University Press, Second Edition

Billis, D. and Harris, M. (1996) Introduction: Enduring Challenges of Research and Practice in Billis, D. and Harris, M. (eds) Voluntary Agencies: Challenges of Organisation and Management Basingstoke: Macmillan 
Cornforth, C., Batsleer, J. and Paton, R. (1998) Opening up Non-Profit Management Development: Lessons from the Open University's Voluntary Sector Management Programme in O'Neill, M. and Fletcher, K. (eds) Nonprofit Management Education: US and World Perspectives Westport, Ct.:

Preagar

Crane, D. (1972) Invisible Colleges: Diffusion of Knowledge in Scientific Communities Chicago, IL: University of Chicago Press

Crouch, M. and McKenzie, H. (2006) The Logic of Small Samples in Interview Based Qualitative Research Social Science Information 45,4 483-499

DiMaggio, P. and Powell, W. W. (1983). The Iron Cage Revisited: Institutional Isomorphism and Collective Rationality in Organizational Fields American Sociological Review 48,2 147-160

Davis Smith, J. (2007) Beyond Social Capital: What Next for Voluntary Action Research? In Davis Smith, J. and Locke, M (eds) Volunteering and the Test of Time: Essays for Policy, Organisation and Research London: Volunteering England and University of East London pp 115-122

Deakin, N. (1996) Meeting the Challenge of Change: Voluntary Action into the $21^{\text {st }}$ Century ('The Deakin Report') London: NCVO

Finnegan, A. and Brewis, G. (2012) The Volunteering England Archive: An Overview and Historical Background Introduction to archive lodged at the London School of Economics

Gerard, D. (1983) Charities in Britain: Conservatism or Change? London: Bedford Square Press

Gidron, B. (2002) Intellectual Challenges During the First Phase of ISTR's Development in ISTR: The First Ten Years in Celebrating ISTR's Tenth Anniversary Baltimore, MD: ISTR 43-46

Gladstone, F. (1979) Voluntary Action in a Changing World London: Beford Square Press

Goldberg, E.M. (1984) Monitoring Voluntary Action Wivenhoe, Essex: ARVAC

Goodman Committee (1976) Charity Law and Voluntary Organisations London: Beford Square Press

Hadley, R. and Hatch, S. (1981) Social Welfare and the Failure of the State London: Allen and Unwin, 1981

Hadley, R., Webb, A. and Farrell, C. (1975) Across the Generations: Old People and Young Volunteers London: Allen and Unwin

Halfpenny, P. and Reid, M. (2002) Research on the Voluntary Sector: An Overview Policy and Politics $30,533-50$

Halfpenny, P., Harris, M., and Scott, D. (2005) History of VSSN at http://www.vssn.org.uk/aboutus/history/ [accessed 22 January 2016]

Hall, P., Land, H., Parker, R. and Webb, A. (1975) Change, Choice and Conflict in Social Policy London: Heinemann

Hall, P.D. (1992) Inventing the Nonprofit Sector and Other Essays on Philanthropy, Voluntarism and Nonprofit Organizations Baltimore, MD: Johns Hopkins University Press

Handy, C. (1981) Improving Effectiveness in Voluntary Organisations London: Bedford Square Press/NCVO 
Harris, M. (2001a) This Charity Business: Who Cares? Nonprofit Management and Leadership 12, 1 95-109

Harris, M. (2001b) The Place of Self and Reflexivity in Third Sector Scholarship: An

Exploration' Nonprofit and Voluntary Sector Quarterly 30, 4 747-760

Harris, M. (2001c) Voluntary Organisations in a Changing Social Policy Environment in Harris, M. and Rochester, C. (eds) Voluntary Organisations and Social Policy in Britain: Perspectives on Change and Choice Basingstoke: Palgrave 213-228

Harris, M. and Billis, D. (1985) Organising Voluntary Agencies: A Guide through the Literature London: Bedford Square Press

Harris, M., Rochester, C., and Halfpenny, P. (2001) Voluntary Organisations and Social Policy: Twenty Years of Change in Harris, M. and Rochester, C. (eds) Voluntary Organisations and Social Policy in Britain: Perspectives on Change and Choice Basingstoke: Palgrave 1-20

Hatch, S. (1980) Outside the State: Voluntary Organisations in Three English Towns London: Croom Helm

Hatch, S. and Mocrofit, I. (1977a) Factors Affecting the Location of Voluntary Organisations Branches Policy and Politics 6, 163-172

Hatch, S. and Mocroft, I. (1977b) The Relative Costs of Services Provided by Voluntary and Statutory Organisations Public Administration 57, 397-405

Home Office (1968) Report of the Committee on Local Authority and Allied Personal Social Services ('The Seebom Report') [Cmnd. 3703) London: HMSO

Johnson, N. (1987) The Welfare State in Transition: The Theory and Practice of Welfare Pluralism Brighton: Harvester

Kendall, J. (2003) The Voluntary Sector London: Routledge

Kendall, J. and Knapp, M. (1996) The Voluntary Sector in the UK Manchester: Manchester University Press

Knapp, M. (1990) Time is Money: The Costs of Volunteering in Britain Today Berkhamsted: The Volunteer Centre

Knapp, M. and Missiakoulis, S. (1982) Inter-sectoral cost comparisons: day care for the elderly Journal of Social Policy 11, 335-354

Knight, B. (1983) Voluntary Action London: Home Office

Kramer, R. (1981) Voluntary Agencies in the Welfare State London: University of California Press

Leat, D. (1977) Research into Community Involvement Berkhamsted: Volunteer Centre

Lee, N. (ed) (1989) Sources of Charity Finance Tonbridge: Charities Aid Foundation

Lewis, D. (2015) Contesting Parallel Worlds: Time to Abandon the Distinction between the

'International and Domestic Contexts of Third Sector Scholarship? Voluntas 26,5 2084-2103

Mendel, S. (2013) A Field of its Own Stanford Social Innovation Review Winter

www.ssireview.org/articles/entry/a field of-its own 
Mullins, N. (1973) The Development of Specialities in Social Science Science Studies 3 245-273

Palmer, P. and Bogdanova, M. (2008) The British are not Coming! UK Higher Education and the Nonprofit Sector Nonprofit Management and Leadership 19,1 79-99

Scott, P. (2013) Why Research Assessment is out of Control Guardian Education 4 November http://www.theguardian.com/education/2013/nov/04/peter-scott-research-excellence-framework [accessed 22 January 2016]

Selwyn, S. (1981) Research into Voluntary Action 1977-80: A Directory Berkhamsted: Volunteer Centre

Shapin, S. (1995) Here and Everywhere: Sociology of Scientific Knowledge American Review of Sociology 21 289-321

Smith, D.H. (2013) Growth of Research Associations and Journals in the Emerging Discipline of Altruistics Nonprofit and Voluntary Sector Quarterly 42,4 638-656

Smith, S.R. (2013) On Receiving the ARNOVA Distinguished Achievement Award http://www.arnova.org/doc/2013/2013RathgebSmithRemarks.pdf

Webb, A. (1979) Voluntary Social Action: In Search of a Policy? Journal of Voluntary Action Research 8, 1-2 8-16

Webb, A. (1985) Alternative Futures for Social Policy and State Welfare in R. Berthoud (ed.), Challenges to Social Policy, London: Gower

Wolfenden, J. (1978) The Future of Voluntary Organisations London: Croom Helm

6, P., and Leat. D. (1997) Inventing the British Voluntary Sector by Committee: from Wolfenden to Deakin Nonprofit Studies 1,2 33-45 


\section{Appendix: Acknowledgements}

The author wishes to thank the following colleagues (listed here in alphabetical order) for giving time to be interviewed for this study and for sharing memories, documents and perspectives. The findings reported here draw heavily on notes of interviews with: David Billis; Michael Brophy; Nicholas Deakin; Jenny Harrow; Stephen Hatch; Martin Knapp; Diana Leat; Ian Mocroft; Foster Murphy; Justin Davis-Smith; Marilyn Taylor; Adrian Webb

Thanks are also due to those who provided publications and advice and/or who shared memories of work in the VSS field in the UK and other countries: Mike Aikin, Jane Andrews, Susan Chambre, Chris Cornforth, Marge Daniels, Ben Gidron, Peter Halfpenny, Mike Locke, Carole Parkes, Colin Rochester and David Horton Smith.

The author is indebted to the staff of the Archives Department of the LSE Library who helped her locate relevant historical documents. 


\section{Figure One - The Emergence and Early Development of UK Voluntary Sector Studies}

Note: Items shown in the two columns in the same horizontal plane were hypothesised by interviewees or in literature to be linked in some way

\begin{tabular}{|c|c|c|}
\hline Date/Period & Events in the UK VSS Field & Contextual Events and Policies \\
\hline 1968 & & $\begin{array}{l}\text { Report of the Seebohm Committee } \\
\text { on the Future of Personal Social } \\
\text { Services (Home Office, 1968) }\end{array}$ \\
\hline 1969 & $\begin{array}{l}\text { Aves Committee Report (Aves, 1969) used } \\
\text { existing research findings and its own } \\
\text { commissioned research on volunteers and } \\
\text { volunteering. }\end{array}$ & $\begin{array}{l}\text { Growing awareness of volunteer } \\
\text { involvement in public sector social } \\
\text { services departments }\end{array}$ \\
\hline $1969-73$ & $\begin{array}{l}\text { Post-Aves Working Party considered Report } \\
\text { recommendation for a body to act as a focus } \\
\text { for information resources about volunteers. }\end{array}$ & $\begin{array}{l}\text { "The Volunteer Centre" established } \\
1973 \text { to collect and disseminate } \\
\text { knowledge about volunteering. }\end{array}$ \\
\hline 1973 & & $\begin{array}{l}\text { Creation of Voluntary Services Unit } \\
\text { (VSU) within Home Office to } \\
\text { coordinate Government interests in } \\
\text { voluntary sector }\end{array}$ \\
\hline 1976 & & $\begin{array}{l}\text { Report of the Goodman Committee } \\
\text { on Charity Law (1976) }\end{array}$ \\
\hline 1978 & $\begin{array}{l}\text { Report of the Wolfenden Committee, 'The } \\
\text { Future of Voluntary Organisations' (1978). } \\
\text { First overview of non-governmental provision } \\
\text { of social welfare services since Welfare State. } \\
\text { Funded by Rowntree and Carnegie } \\
\text { foundations. Commissioned research on } \\
\text { volunteering and voluntary organisations. } \\
\text { Distinguished a 'voluntary sector'. }\end{array}$ & $\begin{array}{l}\text { Collaboration between } \\
\text { governmental and voluntary } \\
\text { organisations in welfare provision } \\
\text { raised as a potential public policy } \\
\text { (e.g. Gladstone, } 1979 \text { and later } \\
\text { work by Hatch and by Webb) }\end{array}$ \\
\hline 1978 & $\begin{array}{l}\text { Founding of ARVAC with involvement of } \\
\text { Volunteer Centre, Wolfenden researchers, and } \\
\text { David Horton Smith from US research } \\
\text { association (AVAS, founded 1971). Later some } \\
\text { funding from Home Office. }\end{array}$ & \\
\hline 1978 & $\begin{array}{l}\text { Establishment of PORTVAC at Brunel } \\
\text { University by David Billis. First UK university- } \\
\text { based specialist research and teaching } \\
\text { programme. }\end{array}$ & $\begin{array}{l}\text { Growing political awareness of } \\
\text { welfare service provision by } \\
\text { volunteers and by non- } \\
\text { governmental agencies }\end{array}$ \\
\hline $1978-83$ & $\begin{array}{l}\text { Wolfenden Committee's research team led by } \\
\text { Stephen Hatch, funded by Rowntree } \\
\text { foundation to continue research on voluntary } \\
\text { organisations. }\end{array}$ & $\begin{array}{l}\text { Hatch and colleagues' post- } \\
\text { Wolfenden publications raised } \\
\text { policy questions about state social } \\
\text { services and proposed 'welfare } \\
\text { pluralism' }\end{array}$ \\
\hline 1979 & $\begin{array}{l}\text { Special Issue of US journal JVAR with pieces } \\
\text { from several UK researchers on the voluntary } \\
\text { sector }\end{array}$ & \\
\hline $\begin{array}{l}1979 \\
\text { onwards }\end{array}$ & & $\begin{array}{l}\text { Thatcher 's Conservative } \\
\text { Government committed to smaller } \\
\text { State; more interest in non- }\end{array}$ \\
\hline
\end{tabular}




\begin{tabular}{|c|c|c|}
\hline & & governmental service provision \\
\hline 1981 & $\begin{array}{l}\text { Publication by Kramer (US academic) of } \\
\text { 'Voluntary Agencies in the Welfare State'. } \\
\text { England is site of one of four national studies. }\end{array}$ & \\
\hline 1982 & & $\begin{array}{l}\text { Barclay Report (1982) recognises } \\
\text { importance of 'informal care' and } \\
\text { 'community social work' }\end{array}$ \\
\hline 1982 & & $\begin{array}{l}\text { Michael Brophy, new Director of } \\
\text { CAF, commits to compile and } \\
\text { publish financial information about } \\
\text { charities and the sector. }\end{array}$ \\
\hline 1984 & $\begin{array}{l}\text { First specialist postgraduate taught course for } \\
\text { voluntary sector practitioners opens at Brunel } \\
\text { University }\end{array}$ & \\
\hline 1985 & $\begin{array}{l}\text { 'Organising Voluntary Agencies: A Guide } \\
\text { through the Literature (Harris and Billis, 1985) } \\
\text { published by NCVO; first published attempt to } \\
\text { delineate the voluntary sector as academic } \\
\text { area }\end{array}$ & \\
\hline 1986 & $\begin{array}{l}\text { International invitation-only conference for } \\
\text { non-profit researchers convened in Bad } \\
\text { Honnef, Germany. Some UK researchers } \\
\text { invited }\end{array}$ & \\
\hline 1987 & $\begin{array}{l}\text { PORTVAC moved to the LSE SPA Department . } \\
\text { Renamed as CVO. }\end{array}$ & \\
\hline 1987 & $\begin{array}{l}\text { MSc in Voluntary Sector Organisation opened } \\
\text { at the LSE }\end{array}$ & \\
\hline 1987 & & $\begin{array}{l}\text { Establishment of ACEVO } \\
\text { (Association of Chief Executives of } \\
\text { Voluntary Organisations) }\end{array}$ \\
\hline 1989 & & $\begin{array}{l}\text { Second international conference of } \\
\text { non-profit researchers in Jerusalem. } \\
\text { Several UK researchers participate. }\end{array}$ \\
\hline Late $1980 \mathrm{~s}$ & & $\begin{array}{l}\text { Policy interest in 'Care in the } \\
\text { Community' as an alternative to } \\
\text { residential service provision. Act } \\
1990 .\end{array}$ \\
\hline 1990 & $\begin{array}{l}\text { First issue of international academic journal } \\
\text { Voluntas with support from UK's CAF and } \\
\text { published in UK . Later becomes journal of ISTR } \\
\text { published in the US }\end{array}$ & \\
\hline 1990 & $\begin{array}{l}\text { First issue of academic journal Nonprofit } \\
\text { Management and Leadership based at Case } \\
\text { Western Reserve University in US but with } \\
\text { editorial support from Billis at the LSE }\end{array}$ & \\
\hline 1990 & $\begin{array}{l}\text { Establishment of Charities Evaluation Services } \\
\text { as an independent charity providing evaluation } \\
\text { advice for voluntary organisations }\end{array}$ & \\
\hline Early 1990s & & $\begin{array}{l}\text { Developing political and academic } \\
\text { interest in supporting 'civil society' } \\
\text { organisations in FSU countries }\end{array}$ \\
\hline
\end{tabular}




\begin{tabular}{|c|c|c|}
\hline $\begin{array}{l}\text { 1990s } \\
\text { onwards }\end{array}$ & & $\begin{array}{l}\text { Shrinking governmental financial } \\
\text { support to UK universities drives } \\
\text { increasing emphasis on income } \\
\text { generation and practice-focused } \\
\text { teaching }\end{array}$ \\
\hline 1990 & $\begin{array}{l}200 \text { attend Annual Conference of AVAS hosted } \\
\text { by CVO, LSE. Brings together UK sector } \\
\text { researchers and facilitates international } \\
\text { networking. }\end{array}$ & \\
\hline 1991 & $\begin{array}{l}\text { Open University starts Voluntary Sector } \\
\text { Management programme and courses. }\end{array}$ & \\
\hline 1991 & Voluntary Action History Society starts & \\
\hline 1992 & $\begin{array}{l}\text { ISTR established, with Voluntas as its journal. } \\
\text { UK researchers involved in establishment and } \\
\text { governance. }\end{array}$ & \\
\hline 1993 & & $\begin{array}{l}\text { Publication of 'Voluntary Action' } \\
\text { report by Barry Knight, former } \\
\text { consultant to the VSU. Suggests } \\
\text { split between independent and } \\
\text { government-funded voluntary } \\
\text { organisations. }\end{array}$ \\
\hline 1993 & & $\begin{array}{l}\text { Third Sector Magazine started } \\
\text { publishing, initially fortnightly. First } \\
\text { successful for-profit magazine in UK } \\
\text { about the sector. Some research- } \\
\text { based content }\end{array}$ \\
\hline 1993-1995 & $\begin{array}{l}\text { Seminar series funded by the ESRC and hosted } \\
\text { by Harris and Rochester at the LSE "Challenges } \\
\text { for Voluntary Agencies in a Changing Social } \\
\text { Policy Environment". Brought together about } \\
40 \text { UK academics, researchers and doctoral } \\
\text { students working on volunteering and } \\
\text { voluntary sector subjects. Agreement at final } \\
\text { seminar to form a 'Voluntary Sector Studies } \\
\text { Network'. }\end{array}$ & \\
\hline
\end{tabular}

